\title{
Lay Patronage and the Development of Ecclesiastical Property in Spanish America: The Case of Buenos Aires, 1700-1900
}

\author{
Roberto Di Stefano
}

\begin{abstract}
Although ecclesiastical properties in Argentina did not reach the scale that made them so notable in New Spain and Peru, an investigation into their origins and evolution provides a good perspective for observing one of the central processes of modern history, secularization, understood not as a progressive loss of religion but as the restructuring and redefinition of the role of religion in individual and collective life. ${ }^{1}$ This article seeks to show, via the vicissitudes of several ecclesiastical properties, that in Argentina the consolidation of the church as a fairly centralized and autonomous institution was a relatively late development, and that the Argentine church, as we understand it today, can be considered the result of a gradual process of secularization during the nineteenth century. ${ }^{2}$
\end{abstract}

Historians often see the colonial church as an entity capable of setting its own goals and strategies and engaging in conflict or cooperation with other actors. ${ }^{3}$

I am grateful to the anonymous $H A H R$ reviewers for their comments, and for the support of my Argentine colleagues Alicia Fraschina, who gave me advice on the literature on the monasteries of New Spain, and María Angélica Corva, who guided me through the labyrinths of the Archive of the Supreme Court of Justice of the Province of Buenos Aires.

Translated from the Spanish by Thomas Holloway. —eds.

I. Danièle Hervieu-Léger, El peregrino y el convertido: La religión en movimiento (Mexico City: Ediciones del Helénico, 2004), 37; and Catholicisme, la fin d'un monde (Paris: Bayard, 2003).

2. Roberto Di Stefano, El púlpito y la plaza: Clero, sociedad y política de la monarquía católica a la república rosista (Buenos Aires: Siglo Veintiuno Editores, 2004); Roberto Di Stefano, "En torno a la Iglesia colonial y del temprano siglo XIX: El caso del Río de la Plata," Takwá: Revista de Historia 5, no. 8 (2005): 49-65; Roberto Di Stefano, "Ut unum sint: La reforma como construcción de la Iglesia (Buenos Aires, 1822-1824)," Rivista di Storia del Cristianesimo 3 (2008): 499-523.

3. Jaime Peire issued an early call for attention to the problems that result from thinking of the colonial church as a social actor in El taller de los espejos: Iglesia e imaginario, 
That image, however, is not reflected in the archival record, which shows instead a constellation of entities that were quite independent of one another, often made up of laymen or clergy, and subject not only to control by the royal patronato but also tied by strict lines of dependency to family groups and other institutions. It is impossible to determine the boundaries of that constellation, because they simply did not exist. A line indicating where "the church" began and ended cannot be drawn in terms of spiritual jurisdiction, to which everyone was subject; nor on the basis of who dedicated property to spiritual purposes, which anyone could do; nor according to membership in the ecclesiastical estate, because laymen could have more influence in decision making than did priests. To be sure, it does not help that church had several meanings. In colonial times the word was applied to the community of believers, to spiritual jurisdiction, to the clergy, to the diocese, and to the physical building. The colonial church was not, however, an institution with the ability to establish its own goals and strategies, a historical actor, a reality distinguishable in fact - and not just conceptually - from society itself. It was not the organization that we know today as the church.

The history of the formation of ecclesiastical patrimony in the Río de la Plata leads us to the history of lay patronage of the eighteenth century, for which we do not yet have reliable studies. ${ }^{4}$ The term lay does not refer to the status of

\footnotetext{
${ }_{17} 67-1815$ (Buenos Aires: Editorial Claridad, 2000), 204-1 I. My view on this topic can be found in the works cited in the previous note. Many examples conceptualize the colonial church as a social actor. In her valuable book on porteño merchants, Susan Socolow claims that they established "an alliance with the Church." Socolow, Los mercaderes del Buenos Aires virreinal: Familia y comercio (Buenos Aires: Ediciones de la Flor, I99I), I I I-27. For María Elena Barral, the church could intervene socially and economically, develop organizational strategies, and carry out "its own organization" in rural areas. Thus Barral views lands devoted to saints and the Virgin that were under the strict control of the donating families as "lands of diocesan Church" and "ecclesiastical properties," for example in the case of the parish of San Isidro. María Elena Barral, "Las propiedades rurales eclesiásticas en el Río de la Plata (Buenos Aires rural en el siglo XVIII y principios del XIX)," in De la Iglesia al Estado: Las desamortizaciones de bienes eclesiásticos en Francia, España y América Latina, ed. Bernard Bodinier, Rosa Congost, and Pablo F. Luna (Zaragoza: Prensas Universitarias de Zaragoza, 2009), II4, I2 I-22.

4. There are none for the Río de la Plata. Furthermore, most studies of lay patronage focus on juridical issues. In Europe several studies appeared in the I 980 os that focused on the system of ecclesiastical benefices, which then directed attention to the beneficent works supported by lay patronage. See, for example, the overview for Italy in Gaetano Greco, "I giuspatronati laicali nell'età moderna," in La Chiesa e il potere politico dal Medioevo all'età contemporanea, ed. Giorgio Chittolini and Giovanni Miccoli (Turin: Giulio Einaudi, I986), $53^{\mathrm{I}-72}$. A pivotal study of benefices as "the specific meeting point of the church with the lay
} 
the founder but to the type of endowment. A priest could establish a lay endowment, and a layperson could establish an ecclesiastical endowment. The latter was created with spiritualized property or property belonging explicitly to a religious institution; lay patronage, in contrast, involved personal property, over which diocesan authority had very limited control. ${ }^{5}$

Religious properties were frequently established under lay patronage in Buenos Aires in the first half of the eighteenth century. The economic and demographic expansion during that century led to a proliferation of chapels and capellanias and the opening of the first two female convents. ${ }^{6}$ Those developments gave rise to problems later in the century as the Bourbon reforms strengthened the authority of the bishops, who then tried, with little success,

world" is Louis Chatellier, "Elementi di una sociologia del beneficio," in Società, Chiesa e vita religiosa nell'Ancien Régime, ed. Carla Russo (Naples: Guida Editori, 1976). There are also case studies such as Antonio Ciuffreda, "I benefici di giuspatronato nella diocesi di Oria tra XVI e XVII secolo," Quaderni Storici, no. 67 (1988): 37-7I; also Carlo Fantappiè, Riforme ecclesiastiche e resistenze sociali: La sperimentazione istituzionale nella diocesi di Prato alla fine dell'Antico regime (Bologna: Il Mulino, I986), 98-I20; Jesús María Pitarque de la Torre, "Los patronatos de laicos en la crisis del Antiguo Régimen: El Señorío de Vizcaya," Hispania Nova, no. 2 (200I-2). A very suggestive study that has greatly influenced research for this article is Elena Brambilla, "Per una storia materiale delle istituzioni ecclesiastiche," Società e Storia 7 (1984): 395-450. The historiography on the Americas had advanced less into these topics.

5. Francisco Ruiz de Velasco y Martínez, Método práctico para los párrocos en la reclamación de memorias-aniversarios y reivindicación de bienes de capellanías por. . . .

(Madrid: Baena Hermanos, 1905), esp. 303-15. A correct explanation of lay patronage and capellanías is Gisela von Wobeser, "El error de Humboldt: Consideraciones en torno a la riqueza del clero mexicano," Fabrbüch für Geschichte Lateinamerikas, no. 40 (2003): $348-49$.

6. On capellanías (chantries or endowments in support of religious functions) and other pious works in Argentina, the most complete study is Abelardo Levaggi, Las capellanías en Argentina: Estudio bistórico-jurídico (Buenos Aires: Instituto de Investigaciones Jurídicas y Sociales "Ambrosio L. Gioja," I992). Considerable work in the historiography of Mexico deals with capellanías as sources of credit. See Michael P. Costeloe, Church Wealth in Mexico: A Study of the Juzgado de Capellanias in the Archbishopric of Mexico, I80o-1856 (Cambridge: Cambridge Univ. Press, I967); Arnold J. Bauer, "The Church in the Economy of Spanish America: Censos and Depósitos in the Eighteenth and Nineteenth Centuries," Hispanic American Historical Review 63, no. 4 (1983): 707-33; Asunción Lavrin, "El capital eclesiástico y las élites en Nueva España," Mexican Studies / Estudios Mexicanos I, no. I (1985): I-28; Gisela von Wobeser, "Las fundaciones piadosas como fuentes de crédito en la época colonial," Historia Mexicana 38, no. 4 (1989): 779-92; and by the same author El crédito eclesiástico en la Nueva España, siglo XVIII (Mexico City: Universidad Nacional Autónoma de México, 1994). 
to reduce or eliminate the autonomy of religious institutions in their dioceses. But lay patronage disappeared only in the course of the nineteenth century as the property was gradually absorbed by the church, often due to actions taken by the state. Taking a long view, in the nineteenth century ecclesiastical property underwent a gradual transition from a system of fragmented holdings that recognized a plurality of rights to a regime that recognized only one owner: the Catholic Church. That shift, in turn, led the church to gradually assume mechanisms of intervention into religious life that families and other institutions had formerly controlled.

\section{The Juridical Framework of Lay Patronage}

The rights of royal patronato that the Spanish monarch exercised over the church in the Indies can be understood as the expansion on a continental scale of the similar rights that a multitude of European families had exercised since time immemorial over chapels, parish churches, and religious communities. Those rights were regulated by canon law resulting from the Councils of Lateran and Trent and the papal decretals, to which Spain added the Concordat of I753. A patron could acquire rights by establishing an endowment fund with the purpose of financing the construction of a church building, or devoting income to the support of religious services and those who conducted such rites. Patrons might achieve that status at times by covering all such functions or at other times by contributing only a part of the package. Thus a given religious entity could have more than one patron. Since rights of patronage could be acquired by the grant of land, financing of construction, or funding of activities, "if someone donates real property, builds the church, and provides for the support of worship services and those who conduct such services, such a person is a patron in three ways. If one person grants the land, another donates funds for construction, and another pays for the services and the officiating clergy, there will be three patrons. In such a case there will be three voices for the appointment of the parish priest or chaplain."7

Over the centuries popes and councils tried to keep such family or lay endowments to a minimum, but the concrete circumstances in which ecclesiastical life evolved made their complete eradication impossible. For example, the Council of Trent established as a general rule the freedom of all churches

7. Antonio Bravo y Tudela, El derecho vigente sobre capellanías colativas de sangre, beneficios y legados pios, patronatos laicales y fundaciones de la propia indole. Comentado, concordado y formulado por. ..., 3rd ed. (Madrid: n.p., I879), 307. 
and benefices from control by their patrons, excepting only those situations in which the would-be patrons could provide proof of the rights on which they based their claim. Remnants of such connections survived, however, in some cases into the twentieth century. Antonio Bravo y Tudela, author of a widely circulated nineteenth-century study of these issues, divided the rights of patrons into those based on "utility" and those based on "honor" granted to the patron. "The former consist of the provision of food to the patron, and an annual stipend if that was stipulated in the founding document. The latter, which in principle the bishop established according to the situation, evolved into more concrete practices, eventually reduced to prerogatives regarding the granting of peace during the mass, incense, candles, place in processions, preferential seating, prayers, burial in the church, placement of coats of arms, and the like, all of which were specified in the language of the founding document." In other words, the patron usually had the right to receive some benefit such as honorific recognition during worship services, display of his coat of arms in the building to show his patronage, or burial inside the church in a symbolically important location. It was customary to specify the rights accruing to the patron in his old age or in case of need. In addition to the endowment specified in the original grant, the patron was obligated to protect, support, and defend the church "along with other obligations established by custom, as long as they did not infringe on the rights of the parish priests, nor involve actual intrusion into matters under their jurisdiction." 8

In the Indies, as a general rule, the rights of patronage of all churches and religious institutions devolved onto the king. But with royal permission a private individual could acquire the same rights as a reward for taking the initiative to build and endow a given institution. A royal decree of I59I and another directed to the bishop of Charcas in 1595 set forth the jurisprudence on this topic. Pedro José de Parras wrote: "Our sovereigns, desirous that in those [American] domains the interests of religion and the places set aside for worship be promoted, granted permission for private individuals resident in those parts to establish monasteries, churches, hospitals, and holy places, receiving in return the corresponding rights of patronage." 9

The Laws of the Indies stated this in the following terms: "It is our will that when a person from his own estate might wish to establish a monastery, hospital, hermitage, church, or other pious work in our Indies, our permission

8. Ibid., 8I-86.

9. Pedro José de Parras, Gobierno de los regulares de la América, ajustado religiosamente á la voluntad del Rey. ... (Madrid: Joachin Ibarra, I783), vol. 2, part 2, chap. 25 , no. 657. 
is based on that which is necessary, carrying out the will of the founders, and that the persons thus called and named should have the rights of patronage, and the archbishops and bishops should have the jurisdiction permitted by law."10

Thus many chapels within the cathedrals of the Indies, like so many in Europe, came under the patronage of the families that had built and endowed them. The family's coat of arms was displayed on the chapel walls and masses were celebrated there for the souls of deceased family members, who were often buried in the same enclosure. ${ }^{11}$ According to Juan de Solórzano y Pereyra, this was never the case at the main altar, which was always under the patronage of the king. ${ }^{12}$

The Laws of the Indies and the royal cédula of 1595 limited the bishop's jurisdiction over entities created or supported under lay patronage. ${ }^{13}$ Control over lay endowments was limited to making sure that the provisions of the donation were carried out. In the case of a chapel in the diocesan cathedral, the approval of the bishop and the ecclesiastical chapter was required. ${ }^{14}$ But outside the purview of the diocese itself, colonial religious institutions enjoyed considerable autonomy, which limited the bishop's range of intervention, especially in peripheral areas such as the Río de la Plata. For example, the regular orders did not need to request the bishop's permission to grant patronage rights to a private party: "All regular prelates in the Indies may grant permission for the patronage of their churches, chapels, convents, hospitals, and other pious establishments. Such patronage may be exercised by the person who established them, with permission from the King. . . . And this practice is in effect, as long as prior permission is requested from His Majesty." 15

Io. Recopilación de Leyes de los Reynos de Indias, vol. I (Madrid: Consejo de la Hispanidad, I943), book I, title 6, law 42J issued by Felipe II in el Pardo, 27 May I59I (my italics).

Ir. M. A. Frances de Urrutigoyti, De Ecclesiis Cathedralibus, earumque privilegiis et praerogativis, tractatus; authore. ... (Lyon, I665), Caput Decimum-sextum: "De Cappellis Ecclesiarum Cathedralium," no. 68: "Sed si Cathedralis, Juris Patronatus Regij fuerit, quales sunt Cathedrales Indiarum [. . . ] dubitatur an Cappellae absque consensu Patroni fundari valeant? In quo dicendum est, non tantum absque consensu, verum invito Patrono fundari \& aedificari posse; cum ex tali constructione Ius non laedatur patronatus, \& Ecclesia \& Cultus diuinus inde augmentum recipiant."

I2. Juan de Solórzano y Pereyra, Politica indiana, vol. 2 (Madrid: Imprenta Real de la Gazeta, 1776), book 4, chap. 3, no. 32.

I3. Parras, Gobierno de los regulares, no. 662.

14. Frances de Urrutigoyti, De Ecclesiis Cathedralibus, nos. 59, 62, 68. Also P. Frasso, De Regio Patronatu. ... (Madrid: n.p., I677), chap. 4, nos. 25, 3I, 4I, 42, 45.

15. Parras, Gobierno de los regulares, no. 664. On the possibility of building monasteries and convents in America without permission from the bishop, see also Solórzano y Pereyra, Politica indiana, book 4 , chap. 23 , no. 13 . 
Solórzano y Pereyra went further, saying that since the monarchs had permitted religious orders to open monasteries on royal authority wherever necessary, "it logically follows that they may establish such institutions without requesting permission from the bishop, or even against the will of the bishop, because royal permission is derived from the Pope himself, who grants it in his name and it is exercised as such in these parts." 16 In addition, as we will see below, there were other limits on the authority of the bishops, including some restrictions in practice that were not established by law.

Patronage rights could be lost through voluntarily ceding those rights or through negligence. In the Indies there was another reason: the construction of a religious building without royal permission. If family rights were lost, the institution was considered to fall under the provisions of the royal patronato.

\section{The Origins of Institutions under Lay Patronage in Buenos Aires}

The archival record regarding entities created under lay patronage in Buenos Aires, although scattered and fragmentary, reveals their importance in the formation of colonial ecclesiastical properties and religious institutions. ${ }^{17}$ At the beginning of the eighteenth century, the diocese of Buenos Aires covered a large, poorly defined, and unevenly occupied territory, dotted with towns where spiritual affairs were in the hands of the scattered members of regular orders and a scarce and weak secular clergy. Most of the parishes were very distant from one another, coinciding with today's provincial capitals. In Buenos Aires, capital of the region and little more than a village at the time, there were a Jesuit college and monasteries of the Franciscan, Dominican, and Mercedarian orders. There were no convents of cloistered nuns. As for diocesan administration, more sees were vacant than filled, the cathedral chapter was made up of three or four dignitaries who shared a paltry income from tithes, and control of the territory was a chimera. At the time Buenos Aires was founded, a single parish existed in the town and surrounding countryside that in I622 was elevated

I6. Solórzano y Pereyra, Politica indiana, book 4, chap. 23, no. 28.

I7. The relevant materials are very fragmentary and dispersed. On I6 June I955, at the height of the conflict between the Peronist government and the Catholic Church, the churches of downtown Buenos Aires and the curia metropolitana were attacked and the rich archives of the archdiocese went up in flames. Since that time, to study the church in the region for the colonial period and the nineteenth century it has been necessary to go to the state archives, especially the Archivo General de la Nación (hereafter AGN). To research the topics that concern us here one must also work in other Argentine and foreign repositories. 
to the status of a cathedral. The care of the flock was in the hands of two parish priests, one for Spaniards and one for natives, and religious life mostly revolved around the monasteries. The spiritual care of the rural population took place in two Indian villages, Baradero and Quilmes, which had parish priests and a few scattered chapels in estancias and hamlets. Rural people who did not belong to the two Indian villages had to "go down to the city" during Holy Week to fulfill their religious obligations.

Economic and demographic expansion over the course of the eighteenth century began to transform both the region and its church. ${ }^{18}$ The Bourbon reforms contributed to the change by measures that turned the secular clergy into a powerful and respectable estate after the expulsion of the Jesuits. Buenos Aires became a viceregal capital in 1776 , ecclesiastical income grew, and the number of priests multiplied along with opportunities for them in capellanías, parishes, prebends, and other positions. Still the vacant sees continued to be more numerous than in the core regions of the Spanish Empire, and the bishop of Buenos Aires never effectively controlled more than a third of the secular clergy, and even less of the regular orders. ${ }^{19}$

The process of expansion began in the first decades of the eighteenth century, when increased economic prosperity and the accumulation of wealth allowed for the construction and funding of chapels and monasteries that were nearly always under the system of lay patronage. These developments also reflected the need to extend spiritual care to a rapidly growing population, both rural and urban. In 1730 the first six rural parishes were created, two of which were in the indigenous villages and the others in private chapels, a pattern that was repeated in subsequent decades when parishes were set up in other areas. ${ }^{20}$

I8. On the expansion of the Buenos Aires region in the eighteenth century see Tulio Halperín Donghi, Revolución y guerra: Formación de una elite dirigente en la Argentina criolla (Buenos Aires: Siglo Veintiuno, 1972), 27-52.

I9. The impotence of the bishops in controlling members of religious orders is evidenced in the Visita ad Limina of the last bishop of the colonial era, Mons. Benito de Lué y Riega, in Vicente Rodríguez Valencia, "La diócesis de Buenos Aires y la Santa Sede en los últimos años del patronato español," Anthologica Annua (Rome) 9 (I96I): 8I7-33.

20. An overview of the organization of parishes in the countryside is María Elena Barral, "Las parroquias rurales de Buenos Aires entre 1730 y I820," Andes, no. I5 (2004). The charter creating them is in Francisco C. Actis, Actas y documentos del cabildo eclesiástico de Buenos Aires (Buenos Aires: Junta de Historia Eclesiástica Argentina, I943-44), 2:232-4I. The histories of towns, sanctuaries, and parishes provide valuable information; see José Torre Revello, Los orígenes y la fundación de la Villa de San Antonio del Camino (La Plata: Archivo Histórico de la Provincia de Buenos Aires, 1932); Juan Antonio Presas, Nuestra Señora del Buen Viaje: Morón (Buenos Aires: Talleres del Instituto Salesiano de Artes 
The first urban parishes, created in 1769 , were also installed in buildings subject to the rights of lay patronage. ${ }^{21}$ Some of the convents in Buenos Aires have similar origins. The first patron of the Recoleta convent was Juan de Narbona. Francisco Antonio de Goycoechea was patron of San Pedro. ${ }^{22}$ The patron of the convent of St. Catharine was Dionisio Torres Briseño. The Ruiz de Arellano

Gráficas, I972); Dedier Norberto Marquiegui, Estancia y poder político en un partido de la campaña bonaerense: Luján, I756-I82I (Buenos Aires: Editorial Biblos, I990); Patricia A. Fogelman, "Reconsideraciones sobre los orígenes del culto a la Virgen de Luján," Entrepasados, no. 23 (2003); J. C. Burgueño, Contribución al estudio de la fundación y desarrollo del pueblo de S. Antonio de Areco (La Plata: n.p., I927); C. M. Birocco, Cañada de la Cruz: Tierra, producción y vida cotidiana en un partido bonaerense durante la colonia (Exaltación de la Cruz: Municipalidad de Exaltación de la Cruz, 2003). On San Vicente see the will of Vicente Pesoa (AGN, Sucesiones 773I), which says that "in the district of La Magdalena, and place called San Vicente, on lands left to me by my deceased parents, and with their blessing, I erected at my own expense a chapel dedicated to San Vicente, which today serves as a parish church, under the conditions set forth in the documents to be found in the Curia Eclesiastica. I did not leave it to the parish because it is on lands that cannot be divided, and I did not know whether I was permitted to do so." The same process took place later in the Banda Oriental, which became Uruguay. See Archivo del Arzobispado de Montevideo, "Epoca colonial: Capillas y Oratorios (Públicos y privados), UruguayArgentina, I, C. 29I, I797-I893." For the case of Córdoba see Archivo del Arzobispado de Córdoba, "Fundación de capillas y oratorios en la diócesis, cementerios e inventarios," "Pagarés, patronatos, división de curatos," and "Fundación y erección de oratorios."

2I. AGN, IX 15-I-25, "Capellanías y patrimonios," ff. 92-I05v: "Ereccion de las seis Parroquias de esta Capital." On the urban parishes of Buenos Aires see "Curatos de la ciudad: Apuntes y noticias," Revista de Buenos Aires 23 (Sept. 1870): r62-66; Julio A. Luqui Lagleyze, Las iglesias de la Ciudad de la Trinidad y Puerto de Santa María de los Buenos Aires (I536-I8IO) (Buenos Aires: Municipalidad de la Ciudad Buenos Aires, I98I); Municipalidad de Buenos Aires, Documentos y planos relativos al período edilicio colonial de la ciudad de BuenosAires, vol. 4, Catedral, Fundaciones religiosas (Buenos Aires: Municipalidad de Buenos Aires, I9Io) (hereafter cited as Documentos y planos). On San Nicolás de Bari see AGN, IX 3I-2-8, "Don Francisco Araujo albasea de Don Domingo Acasuso con los herederos de este por cobro de los gastos echos en la obra de la yglesia de San Nicolas de Vari” [I727]; on Nuestra Señora de Monserrat, AGN, IX 37-I-6, exp. 6, "Dn Pedro Juan Serra y Puyttx solicitando lizencia para pedir Limosna pa la fabrica de la Iglecia de Ntra Señora de Monserrate" [I784]; on Nuestra Señora del Socorro, AGN, IX 31-3-4, exp. 9o, "Imbentario de la Capilla y alajas pertenecientes alapia memoria de Dn Alexandro del Valle" [I779], ff. 7-7v; on La Inmaculada Concepción, AGN, Protocolos notariales, R. 5, ff. 284-286v, "Fundo de capellania Dn Matias flores y su esposa, à favor del lis.do Dn Joseph Flores, cantidad de dos mill ps" [1756]; also Manuel Juan Sanguinetti, San Telmo: Su pasado bistórico, vol. I, I734 al I8o6 (Buenos Aires: Talleres Gráficos de la Penitenciaría Nacional de Buenos Aires, I939), 24-30.

22. AGN, $\mathrm{X}_{4-8-3}$, instrument of foundation of the convent, I3 Nov. I $_{3}$. 
family was the patron of the monastery of La Merced and the first patron of the parish church of San Antonio de Areco, followed by the Del Sar family. ${ }^{23}$ The Casa de Ejercicios was also founded under lay patronage, through the work of the Beata María Antonia de San José. ${ }^{24}$

Although the histories of these institutions are very different, the available sources suggest that from their beginnings they enjoyed a very high degree of autonomy from diocesan authorities. For example, when Goycoechea sought recognition as the "founder, patron, and trustee" of the Recoleta of San Pedro, it was not the bishop but the head of the regular community who conferred the requested privileges "to you and your legitimate heirs." The director of the Casa de Ejercicios, as the founder, had the right to appoint the directors and chaplains with complete independence from the bishop, who was limited to conferring canonical approval. At the time he established the San Isidro church, Domingo de Acassuso stipulated that "under the provisions of this document, in this capellanía, neither in the purchase, distribution, nor administration of its goods and income, nor in the appointment of chaplains, nor in any other matter belonging or pertaining to it, neither His Holiness, his nuncio, nor the bishops of this city, nor his vicars-general, nor any other ecclesiastical or secular person may intrude, aside from the canonical conferral of this endowment on those persons appointed by its patrons."25

The establishment of an institution under lay patronage gave a family a wide range of mechanisms for intervening in religious life. Torres Briceño, for example, gave himself extensive authority over the convent of St. Catharine. He

23. Andrés Millé, La Orden de la Merced en la conquista del Perú, Chile y el Tucumán, y su convento del antiguo Buenos Aires, I2I8-I804 (Buenos Aires: n.p., I958), 210, 213, 247, 264, 387-89. See also Burgueño, Contribución al estudio, 50-56, and AGN, IX 38-7-4, "Autos e incidentes y oposición hecha por parte del convento de Nuestra Señora de la Merced a la ejecución que sigue la presente de las hijas de Don Sebastián de Arellano, contra los bienes del General, Don José Ruiz de Arellano con Doña María Theodora de Suero, su viuda” [I765], and AGN, IX 3I-8-8, "Manifestacion de todos los Bienes raices, Capellanias, y obras Pias qe hace este Conv.to grande de Sn Ramon de Bu.os Ay.s del Rl y Militar orn de Nra. Me y Sra. dela Mrd, a la Junta Sup.r de Consolidadion en virtud de oficio del Exmo Sr Virrey de fha 2 de Abril ultimo," where appear "José Ruiz de Arellano y su esposa María Teodora Suero (nuestros Patronos)" and Teodora Suero "nra Patrona." Also in AGN, IX 7-2-7, "Convento e iglesia de San Ramón de Buenos Aires. Inventario de los bienes muebles e inmuebles, de sus esclavos y rentas fijas, ı8or."

24. Alicia Fraschina, Mujeres consagradas en el Buenos Aires colonial (Buenos Aires: Eudeba, 2010), chaps. 8 and 9.

25. Quoted in Francisco C. Actis, Historia de la Parroquia de San Isidro y de su Santo Patrono, I730-I93o (n.p.: Institución Juan Segundo Fernández, n.d.), 56-63. 
not only appointed the chaplain and specified his functions but also chose several of the nuns on his own authority and in perpetuity, intervened in internal discipline, and even defined the details of the habit. ${ }^{26}$ As a condition for donating the building for the Capuchin convent, Francisco de Araujo reserved to himself the right to continue organizing the celebration of the patron saint, and stipulated that neither the nuns nor "any ecclesiastical nor secular court" could prevent him from doing so. He also claimed the right to appoint as chaplain any of his sons "who might be inclined to the sacerdotal condition," and that any of his daughters who "in the future might be inclined to enter religious life in the convent" could do so, and that they must "be preferred for admission over any other candidate." 27 In other words, although patrons held no authority over spiritual matters, they exercised a heavy hand over the life of the institutions under their patronage.

Patrons also intervened actively in parish administration, which supposedly was under the exclusive jurisdiction of the diocese. Parish priests often served as family chaplains, and vice versa. In San Isidro, where the founding document of the capellanía expressly prohibited the holder from having any other ecclesiastical benefice, chaplains and parish priests changed places fluidly, and it is likely that most of the congregation made no distinction between the functions of one or the other. ${ }^{28}$ Adding to the confusion, the chaplain would at times serve as parish priest in an interim capacity. ${ }^{29}$ In Areco, where there was no impediment such as in San Isidro, the same curate might serve simultaneously as chaplain and parish priest, as the case of Cristóbal Giles shows. There is no doubt, furthermore, that patronage could be an important factor when new parish priests were chosen, despite the system of competition for posts that was supposed to prevent personal connections from affecting the process. When the patron was a member of the clergy, there was a good possibility that he would himself become the parish priest. When Master Roque Ximénez applied to be the priest

26. Fraschina, Mujeres consagradas, 57: "I want their face to be covered by a veil, and they should not show themselves without express permission of the prelate. The robe should be full and in no way ostentatious ... of ordinary linen for the sisters. The footwear of straw or esparto grass."

27. Documentos y planos, 292-95.

28. This is shown in the records reproduced in Aldo Abel Beliera, "Transcripción del Libro primero de españoles de la Parroquia de San Isidro," in Documentos eclesiásticos $y$ civiles de San Isidro, siglos XVIII y XIX (Buenos Aires: Instituto Argentino de Ciencias Genealógicas, Colección Fuentes Documentales, 200I), e.g., 3:28-134.

29. Pedro Oeyen, La Hermandad de Animas de San Isidro, $1785-1869$ (San Isidro: Municipalidad de San Isidro, 2006), 30-3I. 
of Areco, for example, he said in his favor that he "had been the founder of that chapel, as well as its patron." 30 The first parish priest of San Vicente, Vicente Pesoa, was the founder of the church there.

Similarly, a determining factor could be the cleric's membership in the family that held rights of patronage. The only reason that the son of the patron of Nuestra Señora del Buen Viaje — always commonly known as the Merlo chapelwas not its first priest is because he had not reached the minimum age required, but he took the position as soon as he was ordained. ${ }^{31}$ Cristóbal Giles, the adoptive son of the chapel's patron, served the parish of Areco for ten years. Giles held the posts of chaplain and assistant priest until he won the competition for the position of parish priest in 1747.32 Another priest of Areco was Francisco Antonio Suero, nephew of Ruiz de Arellano, son of his sister Juana de Giles and her husband Juan Francisco Suero. When he applied for the competition to be priest of Los Arroyos, Master Ambrosio de Alzugaray claimed that he had done a favor for the congregation by "animating and moving Captain Domingo Gómez, my uncle, so that he would fund the chapel, which he has now done at his own expense, and which Your Lordship has seen fit to elevate to parish church." 33 The curate of the Indians of Buenos Aires, Gaspar Avellaneda, was the brother-in-law of Juan de San Martín, who was patron of the church in which the office was housed. He was followed by Carlos de San Martín, Juan's son. The examples are many and eloquent.

The upgrading of a chapel to the status of parish church meant a considerable increase of resources for the patron family in the form of first fruit offerings, alms, and donations. ${ }^{34}$ The influx of the faithful to fulfill annual religious obligations, for saint's day celebrations, and for Sunday mass justified the opening of a food shop, a beverage shop, and a general store near the church. From those beginnings the emergence of a sizable town was only a matter of time, which led to an increase in church revenue. Because of this expectation many chapels were established on the condition that they would become parish churches. For example, Juan Francisco Suero founded the chapel that became

30. Actis, Actas y documentos, 3:I29; see also Actis, Actas y documentos, 2:258-59; Francisco Avellá Cháfer, Diccionario biográfico del clero secular de Buenos Aires, vol. I, I580-1900 (Buenos Aires: n.p., I983), I26.

31. Presas, Nuestra Señora del Buen Viaje, 27, 31-33.

32. Burgueño, Contribución al estudio, 93, IоI, Iо6; Birocco, Cañada de la Cruz, 36; Avellá Cháfer, Diccionario biográfico, I I 3 . Arellá Cháfer is mistaken in saying that Giles was the brother-in-law of Ruiz de Arellano.

33. Actis, Actas y documentos, 3:157-6r.

34. Birocco, Cañada de la Cruz, 39. 
San Andrés de Giles with the intention that it would be an auxiliary to the parish of Areco, knowing that it would become a parish church in due time. As a condition for the completion of the temple of Monserrat, Juan Pedro Serra stipulated that it would become a parish church and that he would be recognized as its patron. Alejandro del Valle built the chapel of Socorro "with a view . . . to it becoming a parish church, which he then communicated to Our Most Excellent Sir Don Manuel Antonio de la Torre [the bishop], when the latter was considering the erection of new parish churches." The resources a parish church brought in made it possible to finance private worship services without the need to use the family patrimony. Francisco Casco de Mendoza received part of the burial fees charged by the vice-parish. 35 The patron also collected the burial fees in San Isidro and Areco. ${ }^{36}$ When Francisco Merlo donated his chapel to be a parish church he made clear that the priest "was not to receive any of the alms requested for the Holy Image, nor those given voluntarily by any persons or passersby, nor was he to receive the money for burials or funds intended for the building of the church." ${ }^{37}$ In Areco, Giles, and San Isidro, lands whose revenues were dedicated to the worship of the image of a saint or the Virgin (tierras del Santo o de la Virgen, or saint's lands) were rented out to produce income. In some cases, as in Areco, the subdivision and sale of the land around the church financed worship services as well as increasing the size of the town, which in turn caused the income of the parish to multiply. In sum, the promotion of a chapel to vice-parish or parish church became a veritable business enterprise for the family that had provided lay patronage.

A few examples will show the great degree of autonomy that institutions under lay patronage enjoyed, including those that became parish churches or monasteries. One is the urban parish church of San Nicolás de Bari. When Domingo de Acassuso, patron of San Isidro and San Nicolás, died accidentally in 1727 , he left four illegitimate children as his heirs. One of the four, Tomasa, joined in a second marriage with Francisco de Araujo, who inherited the patronage of San Nicolás and completed the construction of the building. In addition to the church proper, the site included cells to be used to shelter "worldly women" and for the establishment of a convent, which Araujo offered to Chilean

35. Ibid., 29 .

36. On San Isidro, AGN, IX 4I-3-6, exp. I9, "Varias instancias de Da Damiana delos Heros y Acasuso sobre que los que estan poblados en tierras del Patronato del Glorioso Sn Isidro dela Costa del Monte Grande paguen los Arrendamientos correspondientes a dicha Senora como Patrona" [1783-I789], f. 28. On Areco, Burgueño, Contribución al estudio, Io7. 37. Actis, Actas y documentos, 3:1 18-19. 
Capuchin nuns. The Capuchins settled in the city in I $749 .{ }^{38}$ The nuns, however, were not satisfied with the quality of construction and the locale, and a few years later they arranged to move the convent to the church of San Juan Bautista, of which Juan de San Martín was patron. ${ }^{39}$ The parish for Indians was located there, under the charge of Curate Jerónimo Avellaneda, brother of María Rosa Avellaneda, who was the wife of Juan de San Martín. Because Jerónimo opposed the transfer of the convent, it was necessary to make a complicated arrangement among the four interested parties: the curate of Indians, the Capuchin nuns, the San Martín-Avellaneda family, and the diocesan authorities. ${ }^{40}$ As a result, in I754 Fr. Carlos de San Martín, son of Juan and nephew of Jerónimo, “exchanged two capellanías he held, worth I,500 pesos, for the position of parish priest of San Nicolás de Bari, and with the approval of the vice-patron and the Reverend Bishop, he entered into service there." 41

The Capuchin nuns moved to San Juan Bautista, leaving space in the church of San Nicolás, which would from that time forward house the parish for Indians with Carlos de San Martín as curate. All indications are that the agreement included donations and sales of plots of land to the benefit of the Capuchin

38. Archivo General de Indias, Sevilla, (hereafter AGI), Audiencia de Buenos Aires, 600 .

39. Documentos y planos, 494.

40. Letter from the ecclesiastical chapter to the king, 8 Oct. I750, in Documentos $y$ planos, 492-95; letter from the abbess to the bishop, Jan. 1752, in ibid., 495-50I. On Avellaneda see Avellá Cháfer, Diccionario biográfico, 89-90; Actis, Actas y documentos, I:269, 272, 298; Actis, Actas y documentos, 2:24I; Actis, Actas y documentos, 3:198-2 10; Hugo Fernández de Burzaco, Aportes biogenealógicos para un padrón de habitantes del Río de la Plata (Buenos Aires: n.p., I987), vol. I, s.v. "Avellaneda, don Gaspar de”; AGI, Audiencia de Buenos Aires, 600, "La Abadesa y Fundadoras del Hospicio de Capuchinas de Buenosayres, solicitando se aprueve la cesion dela Iglesia de Sn Juan Baptista, que les hizo su Patrono dn Juan de Sanmartin; y seles permita que permutandola con la deSn Nicolas, construyan el Monasterio que estan para fundar junto à ella."

4I. AGI, Indiferente general I509, "Relacion de la literatura, grados, meritos y servicios del Doctor Don Carlos de San Martin y Avellaneda, Cura de Naturales en la Parroquial de San Nicolás de Bari de la Ciudad de Buenos-Ayres, Examinador Synodal de aqel Obispado, Comisario, y Calificador del Santo Oficio de la Inquisicion de la Ciudad de Lima, en la referida Buenos-Ayres," n.d. Also AGI, Audiencia de Buenos Aires, 607, "Relacion de la literatura, grados, meritos, y servicios del Doctor Don Carlos de San Martin y Avellaneda, Cura de Naturales en la Parroquia de San Nicolas de Bari, de la Ciudad de Buenos Ayres, Examinador Synodàl de aquel Obispado, y Comisario Proprietario del Santo Oficio de la Inquisicion de la Ciudad de Lima, en la referida de Buenos-Ayres," 20 Dec. I757; AGI, Audiencia de Buenos Aires, 606, "El obispo Manuel Antonio de la Torre sobre sujetos de mérito del clero," 4 May I769. 
nuns and Jerónimo Avellaneda, and the establishment of an endowment so that the uncle could replace the income from the parish priestship that he had lost "because of his illness." 42

As we have seen, the lay patrons of the monastery of La Merced were the Ruiz de Arellano, Giles, and Suero families. In I728 José Ruiz de Arellano had offered his fortune to finish construction of the building on the condition that he would be named patron of the monastery, which the head of the Mercedarian community granted "without delay." 43 Anyone entering the building in the I730s would have seen over the main entrance a painting showing Our Lady of Mercy and the patrons, José Ruiz de Arellano and Rosa Giles, kneeling on her right and left. ${ }^{4}$ The painting took the place of the usual coat of arms, which the family did not have. In addition, the family was the patron of at least two altars. One was the chapel of San José, where their relatives were buried, and the altar facing it, which in 1732 the patron "donated" to the Third Order, of which he was a member, with the proviso that he would pay for it when he had the necessary funds. ${ }^{45}$ In this case, as in San Isidro, the documents allocating funds for the construction of the monastery and adjacent religious buildings stipulated that "no ecclesiastical or secular court" could request an accounting of them. ${ }^{46}$ Other families acquired chapels in La Merced. Fermín de Pesoa bought the altar of San Judas Tadeo and bequeathed it to his descendents in "perpetual donation and award from now and forever" at the time that he established a capellanía, the income from which would pay for the annual celebration of the saint's day. ${ }^{47}$

In Our Lady of Monserrat the disagreements among the "patron of the parish church" Juan Pedro Serra, the first priest of the parish Francisco Antonio Suero, and the rest of the group of Catalonians who established it gave rise to a

42. AGN, Protocolos notariales, R. 4, ff. 447-449v, "Fundasion de capellania que otorga el Gral Dn Ant. ${ }^{\circ}$ de Larrazabal al Doctor Dn Carlos deSamartin" [1754]; AGN, protocolos notariales, R. 4, ff. 6rv-68v, "Esc.ra de venta que haze el Doctor Dn Carlos Samartin de una cassa y sitio afavor de Dn Fran.co Rodrig.s de Vida Sindico Procurador del Convento delas Madres Capuchinas, y fundo de capellania afavor del Mro Dn Geronimo de Avellaneda" [1754]; AGN, protocolos notariales, R. 4, ff. 203-207, "Instrum.to de traspaso de fundo otorgado por el Dr Dn Carlos de Samartin" [1758]; AGN, Protocolos notariales, R. 4, ff. 205-207, "Instrum.to de nuevo fundo otorgado por el Dr Dn Carlos de Samartin áfavor deel Mro Dn Geronimo Abellaneda" [1758].

43. Burgueño, Contribución al estudio, 213.

44. The picture, which still exists, is reproduced in Burgueño, Contribución al estudio, $5^{6-57 .}$

45. Millé, La orden de la Merced, 217.

46. Testamento de Rosa Giles, ${ }_{1733}$, in Millé, La orden de la Merced, 389.

47. Millé, La orden de la Merced, 220-21. 
lively dispute. By Serra's account, when work on the church was halted for lack of funds, the bishop called on him to resume construction, offering in exchange broad permission to collect alms throughout the diocese for a period of ten years. Serra said he accepted the offer "on the condition that once the building was finished it would become a parish church, or at least a vice-parish, and that I would be its patron." 48 Serra's prerogatives in the management of the parish went from the collection of alms to charging for burials, organizing the celebration of the saint's day, and control over the construction and maintenance of the building.

Other court actions swirled around the patronage of El Socorro, forcing the suspension of construction for some years. Francisco Xavier Mazera, whose wife Margarita was the daughter of founder Alejandro del Valle, sued his fatherin-law for reasons now obscure. The situation was complicated by another legal action that an illegitimate daughter of Alejandro, Francisca del Valle, sought against his estate, claiming that she had been treated with ingratitude and injustice after caring for her father during his long and difficult final illness, after which Alejandro's widow and legitimate daughter denied her any inheritance. ${ }^{49}$ As a result of these lawsuits, with only a small portion of the building left to complete, work on it was suspended. Circumstances required that a determination be made as to what part of the project was funded by family wealth and what part was in the public domain. Acting on the case, the interim governor ruled "that regarding the chapel in question with its liturgical vessels and implements, which the deceased constructed and paid for as pious work for public benefit, the chapel and its liturgical furnishings must remain outside the domain of the interested parties Doña Petrona de la Cruz and Doña Margarita del Valle, widow and daughter respectively of the deceased. Only the rights of patronage will be held by Doña Margarita, and her descendants." ${ }^{50}$

With this decision, Francisco Xavier Mazera and his wife Margarita del Valle agreed to assume their responsibilities and held the rights of patronage at least until the long-lived Margarita died in $18{ }_{3} 6$. Thus the courts did not decide "against the heirs of del Valle." 51 The decision meant that Margarita and her husband had to finish work on the parish church and then maintain the build-

48. AGN, IX 37-I-6, exp. 6, "Dn Pedro Juan Serra y Puyttx."

49. AGN, Sucesiones 8733, "Autos que sigue Maria Fran.ca del Valle contra los Bienes de dn Alexandro del Valle" [177r].

50. Ibid., f. I.

5I. That is the interpretion of Luqui Lagleyze, suggesting that in that way the rights of the family were lost, and the church was the beneficiary. See Luqui Lagleyze, Las iglesias de la Ciudad de la Trinidad, I3I. 
ing and see to the needs of its use for worship services. ${ }^{52}$ In her will Margarita ordered that her funeral should be held in El Socorro, "as I am a parishioner and patron of that church." 53

In the parish of the Immaculate Conception and the Capuchin convent we see how various patronage rights could overlap and how they were bought and sold. Matías Flores owned an altar in the old chapel dedicated to Nuestra Señora de los Remedios and San Miguel Arcángel in the Brothers of Charity. ${ }^{54}$ When the brotherhood had accumulated enough funding to move to a lot closer to the center of the city - the present-day parish of San Miguel-Matías bought the whole building from the founder of the brotherhood, Fr. Juan Guillermo González de Islas, and dedicated it to the Immaculate Conception. Later, in I740, he obtained permission from the bishop to ask for alms to support his church and recognition as its majordomo and proprietor in perpetuity. Eight years later he applied for and received recognition of his church as a vice-parish. In 1767 he went one step further, establishing the first altar dedicated to the beato Pedro González Telmo and receiving authorization from the bishop to organize a brotherhood for promoting his veneration among sailors. Finally, in 1769 the vice-parish became a parish church when the urban parishes were organized..$^{55}$ In addition to the alms he collected, Flores received payment for the celebration of mass in his chapel. He received 2,00o pesos from the property of the late Lorenzo Loyzaga, the income from which had previously gone to the Jesuits, and then to the Board of Temporalities for the celebration of the ten o'clock mass on holy days. ${ }^{56}$ After Flores's death, his widow declared insolvency

52. AGN, Sucesiones 8733, "Autos que sigue Maria Fran.ca del Valle," f. 6, where Mazera and Margarita del Valle say they are prepared to provide "whatever is necessary to complete this pious work ... but since the funds from burial fees are so exhausted, Your Lordship should make sure that the description and calculation of what is left to finish consider what is most necessary."

53. AGN, Sucesiones 8609, testamentaría de Margarita del Valle [I836], f. 9rv.

Margarita left two heirs, her daughters Barnabela Josefa Muños from her first marriage and Francisca Macera from the second, but did not indicate whether they would inherit rights of patronage of the church.

54. Documentos y planos, 575-77 [1756], "Solicitud que á Su Magestad elevan los Presbiteros Don Juan Alonso Gonzalez y Don Joseph Gonzalez, en súplica de que por ser fundadores de la Hermandad de la Caridad, se les conceda el Patronato y la Capellania de la Capilla de San Miguel de Buenos Ayres."

55. Luqui Lagleyze, Las iglesias de la Ciudad de la Trinidad, ıо2, Iо7.

56. AGN, IX 7-2-I2, exp. 7, "Capellania de dos mil ps funda[da] en la Iglesia de la Concep.n para qe en ella haia Misa alas diez todos los dias de fiesta, impuesta pr el Pe Rector del Colejio grande de la Comp.a de Jesus de esta Capital, como Patron delas Capellanias que 
because of her "notorious poverty," and the board auctioned off her residence to cover the debt to the endowment fund of the chapel. The family also owed the Dominicans for another smaller capellanía. ${ }^{57}$

Marcos Rodríguez de Figueroa established an endowment for the Capuchin convent before the nuns arrived in Buenos Aires, reserving patronage for himself and his descendants and appointing his nephew Francisco de Cosio y Terán as its first chaplain. Upon the death of Marcos the rights of patronage were to go to "the priest who would be my closest relative." Since the nuns had not been told that they had a chaplain, Marcos ordered in the same document that "the Capuchin Mothers or Poor Clares in the city of Santiago, capital of the kingdom of Chile, should be informed that [the capellanía] has been granted, and that His Majesty the King our Lord should be informed of this." 58 In this case we see the overlapping rights sometimes included in these establishments: Marcos Rodríguez de Figueroa's patronage of the capellanía was added to Francisco de Araujo's patronage over the whole convent, with neither the bishop nor the nuns being informed until after the fact.

The Bishop was a party to these matters but generally had little authority over them. For example, when the diocese tried, on its own account, to choose the director and the chaplains of the Casa de Ejercicios, a legal action forced the bishop's representative to seek the director's approval of the appointments. The decisive argument was that the director - who was herself a layperson - had inherited "the legitimate title of founder." The diocese did not question the rights of the founder to make the appointments but rather the granting of that status to the director, since she had not built the Casa with her personal funds. The lawyer representing the institution successfully argued that even if the founder had built the Casa "using the alms she had collected, the patriarchs of all religious houses have done the same, yet they were still recognized as the legitimate founders. The person who built the parish church of Monserrat in this capital did the same thing, and in a suit brought against Fr. Suero he was not only recognized as the founder, but he was also granted rights of patronage." 59

mando fundar el finado Dn Lorenzo Loyzaga cuia cantidad recivio a reditos Dn Mathias Flores con expecial hipoteca de sus casas" [I75 I].

57. Ibid.; also AGN, IX 7-2-I2, exp. 8, "Recivos dela Capellania de dos mil pesos fundada enla Iglesia dela Concepcion dela Misa de diez que cargan las Casas de Dn Mathias Flores su viuda Da Paula Asturiano, y Autos para la venta de dhas casas apedim.to dela Deudora para el pago de los principales y Reditos qe debe" [1753-I794].

58. AGN, Protocolos notariales, R. 3, ff. 4ov-43, "Instrumento de traspaso otorgado pr Dn. Carlos de Sn Martin" [1736].

59. R. Levene, "El Presbítero Manuel Alberti, director espiritual de la Casa de Ejercicios de Buenos Aires," Boletín de la Comisión Nacional de Museos y Monumentos 


\section{The Disappearance of Lay Patronage}

As early as the first half of the eighteenth century there were attempts to curtail the patronage rights of some families, but the king or the Audiencia blocked them. ${ }^{60}$ The examples of the Casa de Ejercicios and the parish church of Monserrat suggest that there was an increasing tendency to question lay patronage rights when ambiguities arose, especially in the last half of the century with the relative strengthening of the institutional structure of the diocese. At times the available documentation is not adequate to specify the steps in this process, as in the case of the convent of St. Catharine. ${ }^{61}$ The examples for which we have better information show that the loss of patronage rights was sometimes due to the inability of the family to carry out the obligations those rights entailed. This was the case in the Flores family's Immaculate Conception parish, discussed above, the Pesoa family's San Vicente parish, and the Casco family's Exaltation of the Cross parish. By the first years of the nineteenth century the patronage of San Vicente was uncertain. As part of the canonical visitation that Bishop Benito de Lué y Riega carried out in $\mathrm{I}_{803}$, the priest was ordered to verify its status

Históricos 7, no. 7 (1945): I72. The author transcribes all the documentation of the suit. As we see, a key point in determining rights of patronage was whether it was financed by the patron alone, or whether some of the funds came from alms donated by others. For example, in setting forth his conditions for donating his chapel, Merlo declared that it was "done at his expense along with everything in it, without any other parishioner helping in any way." See Actis, Actas y documentos, 3:1 I9.

6o. When the diocesan authorities tried to deny Vicente Morón the right of patronage of the convent of St. Catharine, the king declared "that it is up to Vicente Morón Briceño, by rights of patronage, to present or appoint the priest of his choice for the convent of St. Catharine, according to the wishes of the founder. In the event that there are insufficient funds for its endowment, the rights of patronage will necessarily cease. As founder he may appoint two relatives or poor dependents who must be admitted without a dowry. In general he holds and possesses all rights pertaining to patronage and the capellanía, which rests on his person, and no one may deprive him of the use and exercise of such rights." AGN, Sucesiones 7259, testamentaría de Juan de Narbona [I750], ff. 6ov-6r.

6I. In 1750 Vicente Morón referred to the institution as "my convent." AGN, Sucesiones 7259, testamentaría de Juan de Narbona [ 1750 ]. Later, patronage rights passed to the Gamboa family: AGN, IX 42-6-2, exp. 22, "Autos que sigue Don Juan Martin Mena y Mascarua como Sindico del Monasterio de Monxas de SSanta Cathalina de Sena de esta Ciudad con Don Martin de Gam[boa] sobre que de las quentas de dho monasterio \&a" $\left[\mathrm{I} 745^{-1} 753\right]$. But in $\mathrm{I} 75^{6}$ the prioress claimed that the city council held patronage. AGN, Protocolos Notariales, R. 4, I755-58, f. 3I4v, n.d. but datable in $\mathrm{I}_{75}$ 6, "La Madre María Josefa del Corazón de Jesús, priora dominica, en litigio con Francisco Martín Camacho por suma de pesos," where she refers to "el Illustre cabildo de esta ciu.d y Patron de este Monast." 
so that, in consultation with its parishioners, a decision may be reached regarding the building of a new church, or adequately enlarging the present one. To do this the question of whether the site it occupies is property of the King, or if it belongs to the heirs of Don Vicente Pesoa, must be clarified. If the latter, any funding from his estate for which he might have been responsible must be secured, because he left no accounting of income and expenses, whether coming from burial fees, or from alms he collected, for the building of the church. These matters must be settled with his executors and the bishop informed of the results. ${ }^{62}$

The case of Exaltación de la Cruz is better known. There the bishop, seeing the buildings in a dilapidated state, urged the Casco family to

rebuild and repair the church, providing the funds necessary to support worship services and the administration of the Holy Sacraments, as duties inherent in the honorary rights of patronage, if there are no rents or amounts set aside for a building fund. If the patrons cannot prove their rights, or if they renounce their obligations, the priest and parishioners should carry out the necessary repairs with funding collected from parishioners on a prorated basis, without further delay. ${ }^{63}$

The Casco-Pavon family could not meet the necessary expenses and were obliged to give up their patronage rights. ${ }^{64}$

In the course of the nineteenth century, the institutionalization and centralization of the church in Buenos Aires accelerated the disappearance of the surviving lay patronage arrangements. The decade of the wars of independence broke up the ecclesiastical geography of the region and profoundly changed the system of income, the structure of benefices, and the recruitment mechanisms that had been built up over the previous century. The regular orders, in crisis at least since the I770s, were faced with an uncontrollable lack of discipline, declining membership, and the loss of a good part of their incomes. When in I 820 the fall of the Directorate freed the provinces from the former viceroyalty and left them on their own, the province of Buenos Aires began an ambitious

62. Edgar Gabriel Stoffel, Documentos inéditos de la Santa Visita Pastoral del Obispado del Río de la Plata, I803 y I805 (Santa Fe: Universidad Católica de Santa Fe, I992), 33.

63. Ibid., 23-24.

64. Birocco, Cañada de la Cruz, 246. 
program of modernization in which the reform of the clergy was a central element. The law of December 22, I822, eliminated the fuero personal of the clergy and the tithe, which by that time was reduced to what came into the city from the outlying areas of the province; reorganized the cathedral chapter; and set very demanding requirements for monasteries that only the Franciscans were able to meet. The government took over the properties of dissolved monasteries and those not directly involved in worship services and ministry, and these became the basis for the first governmental budget for church activities. Thus the state church (Iglesia del Estado) came into being as part of the state structures under formation. From that time onward parish churches and other places of worship came to be considered public offices, and the canonical officials and priests became state employees. The problems inherited from the colonial era and the tumultuous revolutionary decade after i 8 io were resolved with a sort of Josephinist solution. The Rivadavian reforms brought a state takeover of the administrative mechanisms and of some properties belonging to private individuals and several religious bodies. The expression "state church" replaced the older plural form common up to the previous decade, "state churches," which referred to the church buildings existing in the territory (of the state) or the dioceses of the United Provinces. The laws and decrees of the revolutionary decade clearly show this change in vocabulary. The resulting organization lasted for almost four and a half decades, from the reform of December I822 until the organization in $\mathrm{I}_{8} 6_{5}$ of the Argentine ecclesiastical province with Buenos Aires as the metropolitan see.

Inventories of instruments, images, and liturgical ornaments illustrate quite well the transfer of property from the hands of families to the state, and then into the ecclesiastical realm. In the colonial era, the parish churches and monasteries that were subject to lay patronage used instruments of worship belonging to the family that held patronage rights. With the reform, such items in one stroke became the property of the state church, and as such were distributed among the churches that most needed them. This had not happened before, although a precedent could be found in the Board of Temporalities, which distributed some property of the expelled Jesuits to other churches. This was a slow process. At least until the middle of the nineteenth century, church inventories show objects with various origins and ownership. Most were articles listed as "of the church," meaning that they belonged to the local religious community. Others were the property of the state, and last were items that continued to be-or appeared to be - the property of private patrons. In July i 824, for example, the trustee of the parish church of Arrecifes sent to the Ministry of Government an inventory of the instruments and ornaments of the church. Included in the 
list was property of the state, such as three "carved and gilded altars," with the marginal note that they were "given by the Supreme Government." Other items were said to have been "paid for" by the "patron and trustee of the new church," including an image of Saint Joseph. Still other items were "of the church," such as the "image of the patron saint, long the property of this parish." There were also objects donated by the church priest or persons listed by name and surname, while others had been acquired with anonymous alms "from the parishioners." 65 It is worthy of note that the property of the religious community ("the church") was specified and distinguished from those items that came from the government or private individuals. This shows the persistence of church property belonging to several different owners. In I835, for example, the government received the inventory of the cathedral parish that operated in the church of $\mathrm{La}$ Merced. Along with the list of articles kept in the church there was an "inventory of those items located in the home of the Patron, Señora Doña Maria de los Santos del Sar," and an "inventory of those items in the possession of Señora de Barquín, Stewardess of the Blessed Virgin of the Niche." 66

As private patronage declined and ecclesiastical organizations became more unified, church property, both fixed and mobile, gradually became the property of the state and church in the form of the state church, and then passed to the national archdiocesan church created in I $_{65}$. In the course of the nineteenth century the curia - with the help of the state, and working to overcome various problems - was able to realize its desire to control the churches, instruments of worship, and sacred images in order to "liberate" the churches. The Civil Code seems to have dealt the coup de grace to multiple ownership rights over ecclesiastical property. It declared that "church buildings and sacred and religious objects belong to the respective churches and parishes.... Such goods can be alienated according to the decisions of the Catholic Church in their respect, and the laws under which the national patronato functions." 67

In some cases either the state or the church (often operating through the state) terminated lay patronage rights and ownership of a church through outright expropriation. The experience of the church of San Isidro is very interesting in this regard and merits a closer look. As previously noted, Domingo de Acassuso established the capellanía and the church building in 1706-7 by

65. AGN, X 4-8-5. Culto I824-1826, "El Sindico de los Arrecifes: Remite el inventario de los utiles de aquella Iglesia."

66. AGN, X 4-9-4. Culto I835-185I, "Inventario de la catedral en la Merced," i9 Feb. I835.

67. Código Civil de la República Argentina (con las notas de Vélez Sársfield) y leyes complementarias (Buenos Aires: Lajouane Editores, 1962), art. 2.345. 
reserving the rights of patronage for himself and his descendants in the most categorical terms. The capellanía was held by his family until the latter part of the nineteenth century, when the provincial government took over the land, which was never donated to the parish.

When Domingo died intestate and without legitimate children, patronage rights passed to one of his illegitimate sons and then to his granddaughter Lorenza Acassuso. 68 In about I768 Damiana de los Heros y Acassuso disputed Lorenza's claims to patronage rights and succeeded in gaining a judgment in her favor from an ecclesiastical court. Lorenza then appealed to the archbishop of Charcas. Apparently the latter issued orders for the appointment of a chaplain until the matter was clarified but in 1774 issued a ruling favorable to Damiana, who then formally assumed the patronage of San Isidro and made an inventory of all its property. Doña Heros y Acassuso presented herself to the ecclesiastical court as "Patron of the Parish Church of San Isidro," appointed chaplains, and collected the income from the saint's lands and part of the income from burial fees. ${ }^{69}$ Of course, she designated her descendents to serve as chaplains, beginning with her grandson Narciso Rodríguez Arévalo, a cleric in minor orders. In I 786, while a royal decree confirmed the family's rights of patronage of San Isidro, Damiana died, leaving those rights to her daughter and only heir, Ana María Fernández Valledor, wife of Pedro Rodríguez Arévalo and mother of Narciso and another young priest, José Eusebio. ${ }^{70}$ Problems recurred in 1796 when Narciso resigned from the capellanía and José Eusebio asked to be appointed in his place. The heirs of the brothers of Domingo de Acassuso, who lived in Viscaya, came forth to dispute that action and claim rights of patronage. They alleged that it was not correct that the father of Damiana, Antonio de los Heros y Acassuso, was the nephew of the church's founder. But the court again ruled in favor of the rights of the Fernández Valledor and Rodríguez Arévalo families. ${ }^{71}$

68. The history of this instance of lay patronage up to 1797 has been reconstructed from information in "Recurso de fuerza interpuesto por los herederos de Domingo Acassuso sobre elección de un capellán" [1797], Archivo Histórico de la Provincia de Buenos Aires, 7.5.I3.7, Recursos de fuerza, leg. 3 .

69. AGN, IX 4I-3-6, exp. I9, "Varias instancias de Da Damiana delos Heros y Acasuso sobre que los que estan poblados en tierras del Patronato del Glorioso Sn Isidro dela Costa del Monte Grande paguen los Arrendamientos correspondientes a dicha Señora como Patrona" [1783-1789].

70. Royal decree issued in Aranjuez, 22 May I786, in AGI, Audiencia de Buenos Aires, 253; the will of Damiana in AGN, Sucesiones 6370, testamentaría de Damiana Heros [I786].

71. Archivo Histórico de la Provincia de Buenos Aires, 7.5.13.7, Recursos de fuerza, leg. 3 , "Recurso de fuerza interpuesto...." 
From then on the rights of patronage were handed down with no further legal challenges. In 1856 the lawyer of the patron Nicanor Arévalo explained, without being very precise, that

in the year I780 Doña Ana Maria Fernández Valledor, the grandmother of my client, was declared patron of the capellanía. At the turn of the century the patronage fell to my client's uncle Don José Arévalo and later to another uncle named Don José Eusebio Arévalo. The latter was declared patron and chaplain and assumed the capellanía. In I83 I Don Domingo Arévalo, the father of Don Nicanor who presently holds patronage, became patron, as confirmed by the documents which I respectfully attach. Since he received patronage rights in January of I 856 he has installed a chaplain who continues in that post, meeting all necessary expenses to this day. ${ }^{72}$

Nicanor was the last patron. When the municipality of San Isidro was created in 1855 the town, succeeding the provincial government, became involved in the matter. ${ }^{73}$ Upon discovering in 1856 that the patron did not live in San Isidro and was not fulfilling his duties, the city government initiated a legal action that was resolved by an agreement in I864. By the terms of the settlement the town would collect the rents from the saint's lands to finance the activities of the capellanía, while the patron would continue to receive the proceeds from other endowment funds. ${ }^{74}$ This arrangement could not last for long, however, because by then neither the state nor the church, for different reasons, was willing to tolerate the continuation of entailments of that nature. In the case of the state, the goal was to disentail such properties in order to integrate them into the privatized real estate market. For the church, it had become unacceptable for a layperson to exercise rights, such as the appointment of a chaplain, that were considered inappropriate for someone of lay status. There was a third party in the dispute, which made it necessary to hurry toward a resolution: some renters and occupants of farms on the saint's lands began to claim property rights based on their lengthy occupation. ${ }^{75}$ Thus the converging interests of the provincial

72. AGN, X 28-9-8, exp. 3.I69, "Arevalo Don Nicanor sobre una capellania" [1856].

73. Jorge André Lavalle and Alberto N. Manfredi Jr., San Isidro en los tiempos de la Corporación Municipal, I856-1886 (San Isidro: Municipalidad de San Isidro, 2003), 71-82.

74. Ibid., $135-37$.

75. Departamento Histórico Judicial, Archivo de la Suprema Corte de Justicia (La Plata), leg. 37, exp. 3.400, "Rolon Don Martin contra la Municipalidad de San Isidro sobre apertura de calle" [I891]. 
and municipal governments and the Catholic Church led to the state's expropriation of the saint's lands and the church building, a process that began in I 858 and was settled by a decision of the Supreme Court in $1885 .{ }^{76}$

An even later example of expropriation, in this case by the church without the intervention of the state, was in Santa Fe, where the diocese took over the sanctuary of the image of the Virgin of Guadalupe. An episcopal decree of February 28 , I900, declared that the chapel had been "constructed with alms of the faithful" and that it was "indispensable for Ecclesiastical Authority, which has all rights to supervise and exercise jurisdiction over sacred places, among which are the chapels and public oratories, to exercise those rights over the church and chapel called Guadalupe." On that basis it was decreed, without further ado, that beginning on March I5 the chapel was "entirely subject to Ecclesiastical Jurisdiction, as are all other churches and chapels in the diocese," and that until a chaplain was appointed, the interim rector of the parish of El Carmen would take charge of its administration, prohibiting the exercise of "any other religious function" without express permission. ${ }^{77}$

The bishop's ruling was not carried out without resistance and objections. Antonia Godoy, patron and owner of the chapel, responded respectfully that she wanted "to make some statements and provide explanations that she believed necessary to establish the truth regarding this Sanctuary and establish my true situation with respect to it," to wit:

This church was constructed on land that is my exclusive property.

The nave was built with funds donated by Don Ventura Coll, and the chapel tower and eastern side aisle with the alms of the faithful. All these works were carried out under the direction of my ancestors who,

76. Pedro Francisco Kröpfl, La metamorfosis de San Isidro, 1580-1994: Reseña de la bistoria y desarrollo del Partido (San Isidro: Editorial Trenque Lauquen, I994), 86-87. The ruling of the Supreme Court, which makes clear that the conflict is over the San Isidro church, is in Archivo de la Suprema Corte de Justicia, leg. II, causa I.545, "Acuso recibo de la resolución dictada por la Corte en el expediente seguido por Nicanor Arévalo sobre reducción de una capellanía" [1885]; also in Digesto eclesiástico argentino: Recopilación de leyes, decretos, bulas, pastorales, constituciones, etc. que se refieren a la Iglesia nacional (Buenos Aires: Imprenta Especial de Obras, 1880), 212-13.

77. Archive of the Archdiocese of Santa Fe, "Parroquia de Guadalupe, I: 1822-1946," "Auto del Ilmo Señor Obispo Diocesano de Santa Fé sobre el Santuario de Ntra Sra de Guadalupe," 28 Feb. I900. The documents on the same case cited below are located in the same file. See also "Circular prohibiendo la celebración de la Misa fuera de las Iglesias bendecidas, Oratorios públicos y semipúblicos legitimamente erigidos," I5 Sept. I900, Boletín Eclesiástico de la Diócesis de Santa-Fé I, no. 6, Sunday, i6 Sept. I9oo, pp. 91-92. 
down to the undersigned, have with fervent love and respect cared for this church of the miraculous virgin to which it is devoted. The other parts of the building, including the sacristy, were built by my parents and grandparents and partly with funds from my personal holdings. I have constructed the building that exists alongside the church and in it I want to dedicate the rest of my life in adoration of the Blessed Virgin of Guadalupe and live in the house where for more than a century my ancestors have lived.

In view of this long history of possession, for Antonia it would be "extremely painful to leave the Sanctuary of my predilection and the house of my dearest affections." Taking recourse in the rights of property, possession, and domain that the law provided, the lady advised the prelate that she would continue "living in the house that I have caused to be built for that purpose, next to the church." Evidently there were no possible grounds for claiming ownership of the site and the chapel, but the image was another matter: "Recognizing and accepting the supervision and jurisdiction of Ecclesiastical Authority over the chapel I am disposed and pleased to turn it over, under inventory, with its ornaments, images, and whatever exists within the church building, to the representative of the Lord Bishop, with the exception of the bust of the Blessed Virgin of Guadalupe, which belongs to me and it is my will not to part with forever."

Meanwhile, the bishop took advantage of an offer by parishioners González and Demaria to "provide to Your Lordship all our will and support, requesting that you let us know how we may be useful," informing them of the need for "a monthly subsidy, arranged among the parishioners" for the support of the chaplain. He would reward the two parishioners for this "providential" offer by declaring them not only as "participants in, but as the initiators of the subsidy, either putting you in charge of it, or by placing your name at the top of the list." Thus in I90I a committee was organized and charged with the works, and with guaranteeing funding for the chaplain, excluding the previous owner, Antonia Godoy.

Antonia did not give up, however, and in January I9or she went on the offensive. When the inventory of the chapel was conducted she took the beloved image she claimed as family property to her home. Cornered but determined not to yield, she decided to donate the image to the Dominican monastery, which received it with a jubilant ringing of the bells. The infuriated bishop declared that the donation had been made "without requesting permission of any kind from this Curia, because the Reverend Prior had decided it was not 
necessary." The bishop further declared the gift to be "null and void and without effect." His argument was based on "the express decision of the Plenary Council for Latin America that ... devout images displayed in any church for the special veneration of the faithful cannot be transferred to any other church without Apostolic blessing," and ordered that the image be brought to the cathedral immediately "without ceremony of any kind." The record concludes that "the image was immediately removed, with the consent of the Reverend Prior."

\section{Buenos Aires, an Exception?}

In Buenos Aires, there was not the wholesale transfer of church properties to the state, as occurred in other countries through liberal reforms, but the transfer of properties from many family and corporate entities to both church and state. The history of patronage shows that properties subject to multiple rights, overlapping at times, were transformed in various ways into properties of the church or the state. Church and state invoked similar principles when expropriating properties. The state claimed to be in charge of "public service," and the church claimed a monopoly on "public worship." The nineteenth-century drive to disencumber property aimed to "transform property that was stagnant and entailed in private institutions into property that was held in individual private hands, free and circulating." 78 To do that it was necessary to unify the multiple mechanisms for financing religious activities under the control of the state and the church. Thus it is not surprising that in 1856 the legislature approved a law making the bishop the only possible patron for any capellanía established from that time forward. ${ }^{79}$ The actions of the church and the state complemented one another, and both institutions were strengthened in the process.

The appropriation of properties held under lay patronage was consistent with other nineteenth-century processes. One of these was the progressive clericalization of religious life, as can be seen in several initiatives of the church hierarchy. In I835 Bishop Mariano Medrano issued a "pastoral order on ecclesiastical dress" by which priests were required to wear the cassock. ${ }^{80}$ In 1856 Bishop Mariano Escalada decided to appoint clerics to replace all laypersons

78. Levaggi, Las capellanías en Argentina, I4I.

79. Diario de sesiones de la Cámara de Diputados, Año de I857 (Buenos Aires: Imprenta de "La República," I883), 5; Diario de sesiones de la Cámara de Senadores del Estado de Buenos Aires, 1857 (Buenos Aires: Imprenta de El Orden, I858), I I4-23.

80. Digesto eclesiástico argentino, I68-7 I. 
who held positions in the cathedral. ${ }^{81}$ The appropriation of properties implied, in fact, a general reduction of the participation of laypeople in religious life. Owning a parish allowed a layperson to participate in the choice of its priest. The patron of a convent could exercise rights of approval over its chaplain and choose a number of its nuns. The collection of alms was important in the spread of devotions over vast expanses of territory. The church's progressive takeover of buildings, images, and other assets was part of a gradual monopolization of control over religious life.

To what extent might this pattern be generalized to other regions? Can the colonial church be considered a true historical actor in other parts of the Spanish Empire? As a general statement, it would seem that until the eighteenth century the church was everywhere a collection of institutions that were too independent of one another and dependent on family groups and the crown to be considered a unitary social actor. All indications are that in New Spain, the church had achieved a high degree of institutional integration already in the first half of the eighteenth century. ${ }^{82}$ Even there, however, the plural character of colonial religious institutions has been a matter of comment. ${ }^{83}$ It has even been claimed that the consolidation of the church in Mexico was also a nineteenthcentury phenomenon. ${ }^{84}$ How does this situation compare to developments in Europe? A recent study of Parisian convents emphasizes the importance of lay patronage in their operation, providing a picture of a post-Tridentine church that was much less centralized than is often assumed. ${ }^{85}$ Such a configuration of religious activities should not be surprising in societies where the monarchies themselves gained obedience through the corporate structures of the society of

8ı. Cayetano Bruno, Historia de la Iglesia en la Argentina, vol. io (Buenos Aires: Editorial Don Bosco, I975), 266.

82. Oscar Mazín Gómez, El cabildo catedral de Valladolid de Michoacán (Zamora, Michoacán: El Colegio de Michoacán, I996), esp. 301-7, 340-41.

83. Annick Lempérière, Entre Dieu et le roi, la république: Mexico, XVIe-XIXe siècle (Paris: Belles Lettres, 2004), 34-38. The fragmentary nature of the church is also noted in David Carbajal López, La política eclesiástica del estado de Veracruz, I824-I834 (Mexico City: INAH, 2006), esp. IO, I37. In her excellent book Los conventos femeninos y el mundo urbano de la Puebla de los Ángeles del siglo XVIII (Mexico City: El Colegio de México, 200o), I9I, Rosalva Loreto López states that the colonial Spanish American church "is in reality a mosaic of diverse institutions."

84. Lempérière, Entre Dieu et le roi, 34-38.

85. Barbara B. Diefendorf, "Contradictions of the Century of Saints: Aristocratic Patronage and the Convents of Counter-Reformation Paris," French Historical Studies 24, no. 3 (2001): 469-99. 
estates. ${ }^{86}$ Even the Bourbon reforms would have been impossible to implement except through the local elites. ${ }^{87}$

The patterns we have examined are common throughout the Hispanic world. Asunción Lavrin states correctly that the convents under lay patronage "became an extension of those families." 88 The relationship between the Santa Clara convent in Cuzco and its patron family was so close that it was difficult to differentiate the properties of one from the other. ${ }^{89}$ The lay founder of the convent of Nuestra Señora de los Remedios in Cuzco was "a combination of de facto prioress, trustee, and administrator." 90 In the monastery of Santa Teresa in Puebla, José Gómez de la Parra bought nothing less than the right to "hold the key to the Blessed Sacrament on Holy Thursday for all the rest of his days" and to bequeath it to his descendents. ${ }^{91}$ In 1626 the Dukes of Olivares established a convent reserving "overlordship and perpetual patronage for themselves and their successors," with the right to decide "the number of nuns who would be received into the new community, as well as their origins and their personal qualities." The number could only be increased if "a daughter, granddaughter, or great-granddaughter of the patron" wished to enter the convent. ${ }^{92}$

In some cases lay patronage was terminated for reasons similar to those examined above. In Puebla in I67 I, for example, a Dominican established a brotherhood dedicated to Santa Inés de Montepulciano, with permission from

86. J. H. Elliot, “A Europe of Composite Monarchies," Past and Present, no. 137 (1992): 48-7I; Antonio Manuel Hespanha, Vísperas del Leviatán: Instituciones y poder político (Portugal, siglo XVII) (Madrid: Taurus, I989); on the Río de la Plata, Zacarias Moutoukias, "Gobierno y sociedad en el Tucumán y el Río de la Plata, I550-1800,” in Nueva Historia Argentina, vol. 2, La sociedad colonial, ed. Enrique Tandeter (Buenos Aires: Editorial Sudamericana, 2000), 355-4II.

87. For example, Federica Morelli, Territorio o nazione: Riforma e dissoluzione dello spazio imperiale in Ecuador, I765-I830 (Soveria Mannelli: Rubbettino, 200I).

88. Asunción Lavrin, "Religiosas," in Ciudades y sociedad en Latinoamérica colonial, ed. Louisa Schell Hoberman and Susan M. Socolow (Buenos Aires: Fondo de Cultura Económica, I993), I8I-82.

89. Kathryn Burns, Hábitos coloniales: Los conventos y la economía espiritual del Cuzco (Lima: Quellca / IFEA, 2008), 85-86.

9o. Ibid., I05-6.

91. Francisco Javier Cervantes Bello, "Las fundaciones piadosas del convento de Santa Teresa, en Puebla de los Ángeles, siglos XVII-XVIII," in Fundadores, fundaciones y espacios de vida conventual: Nuevas aportaciones al monacato femenino, ed. I. Viforcos Marinas and M. Dolores Campos Sánchez-Bordona (León: Universidad de León, 2005), 542-43. 92. Francisco Amores Martínez, "Las fundaciones y patronatos conventuales del Conde Duque de Olivares," in Viforcos Marinas and Campos Sánchez-Bordona, Fundadores, fundaciones y espacios de vida conventual, 218-I9. 
the superiors and prelates in his order, not the bishop. In the charter he reserved for himself certain patronage rights, such as management of the properties. Some years later the brotherhood was transformed into a beaterio (residence for lay sisters), and he joined with Idelfonso Raboso to construct the buildings. Raboso was the father of three Dominican nuns who requested that instead of a beaterio he would build a convent so that they could "enter it and acquire glorious fame as its resident founders," but the project was not carried out right away. At the end of the seventeenth century, after the death of its founder, the beaterio and its founding family found themselves in economic straits, and Raboso's widow proposed "to sell the unfinished beaterio and abandon the patronage of it." In I 7OI the king approved the establishment of the convent, but it would be "subject and entirely subordinate to you [the bishop] and the successor bishops of the Church of Puebla." This gave rise to protests from the Dominican friars, who wanted the establishment to come under their jurisdiction..$^{93}$ In this case, again, political authorities turned over a family institution to the diocese.

To the extent that we can generalize from these examples, it is interesting to look at the processes and rhythms by which each case came under centralized authority. Multiple actors were involved in the transition, most fundamentally the state, the diocesan authorities, and, in the nineteenth century, the Holy See. If in colonial times action by the crown was the decisive factor, we might suppose that the transformation took place earlier in the regions of greatest economic and political importance. This could explain, for example, why features that persisted in the Río de la Plata well into the nineteenth century had been lost much earlier in New Spain. Economic and political disparities would explain the lag in the processes of centralization. In principle, in New Spain the power of family and corporative lay patrons would have been relatively less important, due to the greater resources in the hands of the diocesan structures. On that more solid base, Bourbon policies would have acted in two different ways to push for consolidation: on the one hand by further strengthening diocesan power over autonomous institutions (for example, in the secularization of the parish churches in 1749$),{ }^{94}$ and on the other hand by involuntarily provoking a collective reaction from the bishops against efforts to control certain economic resources. The economic and institutional strength of the bishops of New Spain enabled them to join together very early to challenge some poli-

93. Loreto López, Los conventos femeninos, $72-77$.

94. David A. Brading, Orbe indiano: De la monarquía católica a la república criolla, I492-I867 (Mexico City: Fondo de Cultura Económica, I99r), chap. 23, "La Iglesia erastiana." 
cies of the crown. In the I730s they organized to oppose royal appropriation of the income from vacant prebends. Historians have correctly commented on "a widespread movement of political coordination" among the dioceses of New Spain. ${ }^{95}$ The churches of Mexico City, Valladolid, Puebla, and Oaxaca joined together again in 1787 to protest the powers of the intendants over tithes. ${ }^{96} \mathrm{On}$ both occasions the bishops, led by the archbishop of Mexico City, agreed on a collective course of action.

In the Río de la Plata, in contrast, lay patronage persisted and some aspects of the consolidating process did not appear until well into the nineteenth century. At the beginning of that century Buenos Aires was the only viceregal capital that did not have its own archbishop. Due to the upheavals of the independence era and a lack of communication with Rome, that situation lasted until the creation of the archdiocese in 1865 . The Argentine bishops did not meet to work out a collective pastoral charter until I 889 , a century and a half later than their counterparts in New Spain. ${ }^{97}$ It is also significant that in the Río de la Plata no cultural identity based on religious principles had been forged analogous to what had taken place in New Spain. ${ }^{98}$ There, delegates from all dioceses proclaimed the Virgin of Guadalupe their patron in I739. That act was a symbolic manifestation of the process of shaping a "vigorous coalition, although confined to the churches of New Spain," which claimed the "immemorial right" of the cathedrals to organize public worship and their ancient prerogatives in the face of the policies of the crown. ${ }^{99}$ In the Río de la Plata the absence of a devotional focus that would fulfill such a role revealed the lack of integration among its dioceses and a lack of awareness of common interests to defend. It was not until the end of the nineteenth century that Argentine Catholicism proposed the Virgin of Luján, the devotional cult of the most dynamic region of the country, as the nation's patron saint. 100

The other great centralizing factor was the action of the Holy See, which

95. Mazín Gómez, El cabildo catedral, 301-7, 340-4I.

96. Ibid., $388 f$., where we read that faced with the resistance of the bishops the new minister Antonio Porlier stepped back from this measure, while protesting the coalition of the dioceses.

97. Documentos del episcopado argentino, vol. I, I889-19o9 (Buenos Aires: Conferencia Episcopal Argentina, 1993), 22-43.

98. See, for example, Brading, Orbe indiano, and from the same author Mito y profecía en la historia de México (Mexico City: Fondo de Cultura Económica, 2004).

99. Mazín Gómez, El cabildo catedral, 307-I2, 341.

Ioo. Jesús María Binetti, El augusto recinto: Conflictos y debates tras la construcción de la Basílica de Luján (Luján: Librería de Mayo, 2007). 
in the course of the nineteenth century took control over the universal church. An example directly concerning the theme of ecclesiastical patronage will suffice to illustrate that trend. The Code of Canon Law of I9I 7 took a fundamental step in the process of appropriation by making the Roman pontiff the "supreme administrator and dispenser of all church property," and the head of each diocese the guardian of all properties in the territory under his charge. ${ }^{101}$ By the early twentieth century the ecclesiastical leviathan had reached maturity.

Ior. Código de Derecho Canónico y legislación complementaria (Madrid: Biblioteca de Autores Cristianos, I952), canons I5I8 and I5I9. 